\title{
FURTHER STUDIES ON THE MAIN ONION INSECT PESTS IN STORE AND THEIR EFFECT ON YIELD LOSS IN FAYOUM, GOVERNORATE
}

\author{
SABRA, I. M., H. A. SALEH AND I. A. EL SAPPAGH
}

Plant Protection Research Institute, ARC, Dokki, Giza, Egypt

(Manuscript received 5 January 2011)

\begin{abstract}
An experiment was conducted on stored onion pests in Fayoum governorate to determine the main insect pests, symptoms of damage, population fluctuation to evaluate its effect on yield loss throughout 2008/09 and 2009/10 seasons. The results revealed that Eumerus amoenus Loew, Ephestia cautella (Walker), Carpophilus immaculatus Luc., C. hemipterus F. and Athrigona orientalis Schin were the main insect pests of onion bulbs in store. The symptoms of damage for E. cautella and Carpophilus spp were described and population of obtained pests were studied. The roles of these pests in yield loss were considered by weight or either number of infested bulbs (\% infestation). The detected pests were arranged descendingly according to the infestation percentage in 2008/09 and 2009/10 seasons as: E. amoenus (10.8\& 8.3\%), E. cautella (8.8\&7.7\%), Carpophilus spp. (7.2\&6.0\%) and A. orientalis (2\&1.5\%). The observed pests often destroy the infested bulbs completely except $E$. cautella. The weight loss percent caused by the insect pests ranged 25.78 and $24.10 \%$ of the total weight loss.
\end{abstract}

\section{INTRODUCTION}

Onion, Alium cepa L., is an important exported field crop. It cultivated frequently as a main winter crop in Fayoum in a large area. It used as fresh green onion, onion bulbs or food industry. At the end of the growing season, after bulbs formation, the onion bulbs are attacked with many insect pests and the infestation continued in the stores which reduces the quantity and quality of storage bulbs. In Egypt, Mahmoud (2008) observed Eumerus amoenus Loew, Ephestia cautella (Walker), Carpophilus hemipterus F., C. immaculatus Luc., and Athrigona orientalis Schin infesting onion in the store. Also, Massry (2002) reported that, the percent of $E$. amoenus in store varied from 5 to 30\%. El-Sherif and Mahmoud (2008) reported that, the larvae of the onion bulb fly ( $E$. amoenus) was the most serious pest threatening stored onion bulbs throughout the storage period extended from early June to early November. In India, Gupta et al, (1991) reported that, A. orientalis and C. obsoletus infest onion bulbs in store.

The present study aims to determine the main harmful insect pests of onion bulbs in store under Fayoum conditions and throw the light on their population and 
infestation symptoms. Also, to assess the effect of these pests on the weight after storage period.

\section{MATERIALS AND METHODS}

To survey the main insect pests of onion bulbs in the store and to clarify their effects on the yield, an experiment was carried out in Fayoum Governorate on stored onion bulbs (Giza 20 variety) throughout 2008/9 and 2009/10 seasons.

\section{A- Survey Studies}

The experiment was carried out in open onion field stores (trade stores) in piles each measured $2 \mathrm{~m}$. wide $\times 10 \mathrm{~m}$. long $\times 70 \mathrm{~cm}$. height and covered with dray rice straws. Monthly five samples each 100 bulbs were randomly collected from June to October. The samples were directly transferred to the lab. to dissect the bulbs and collect the insects. The specimens of insects were identified by Taxonomy Department of Plant Protection Research Institute.

\section{B-Population Studies}

To study the population of onion insects, one tone of Giza 20 variety was stored from May to next April and exposed to the natural infestation. Monthly five samples of 100 bulbs each were collected and examined to record the counts and the infestation percent.

\section{C- Loss assessment}

Infestation with any of $E$. amoenus, Carpophilus spp, A. orientalis causes a complete destruction of the bulbs which were completely lossed. Most of the infested bulbs have mixed individuals of these pests. On the other hand the infestation with $E$. cautella not combined with the other insects and causes drying of the outer peels of bulb, so their effect on yield was studied separately. In this respect, Mahmoud (2008) found that, yield loss reach maximum $(88.3 \%)$ at 100 bulb infestation with $E$. amoenus. According to this fact, weight the infested bulbs is difficult and not true, so the weight loss of stored onion in this paper, was considered by either percent of infested bulbs or their lossed weight. Weight loss assessment was done through an experiment carried out in an open field store, contained fresh bulbs, during June and exposed to the natural infestation. Ten samples of 100 healthy bulbs, each were collected and weighted before storing. At the end of storing, in October, ten samples of 100 bulbs each were randomly collected and screened to separate the infested bulbs than that of healthy ones. Onions of each sort were weighted to obtain total loss, natural loss as a result of moisture reduction and loss caused by insect pests. The loss was calculated according to the following equation. 
Total loss $\%=$ Weight before storage - weight after storage $\_$$\times 100$

Weight before storage

Natural loss $\%=W$. of 100 bulbs before storage $-W$. of 100 healthy bulbs after storage $\times 100$

W. of 100 bulbs before storage

$\%$ Loss caused by insect pests $=$ Total loss - Natural loss

\section{RESULTS AND DISCUSSION}

\section{A- Survey Studies}

Survey of bulb insects found in onion stored at Fayoum governorate during the period from June, 2008 to May, 2010 revealed the existence of five injurious species belonging to four genera, Eumerus amoenus Loew, Ephestia cautella (Walker), Carpophilus hemipterus F. and Carpophilus immaculatus Luc., and Athrigona orientalis Schin.

\section{Carpophilus spp.}

This study revealed that, the two species of dried fruit beetles, $C$. hemipterus and $C$. immaculatus attack onion bulbs in the field after completing the bulb formation and also at harvest. Larvae of the two species are nearly similar and their infestation symptoms may combine, so they are studied as one genus. The infestation continued in store all over storage period. Large numbers of larvae feed internally on bulb tissues while the adults dig bits on the outer leaves of the bulbs. Their infestation may combine with onion fly $E$. amoenus and the beetle may carry yeast cells, fungi and bacteria into the bulb causing sour rot which completely destructed the bulb.

\section{E. cautella (Walker)}

The almond moth E. cautella (Walker) is a major worldwide pest of stored foods. Survey studies revealed that, its larvae feed externally on bulbs under the outer peels of onion only in store. The larvae enter the bulb by digging a small entry holes (about 1/2-1 m.m) or throw the top of the bulb. The infestation causes a partial drying for bulbs outer leaves or rarely causes a complete drying and the leaves color become black or dark brown. Therefore, the growing point not developed and these bulbs become unmarketable. The infested bulbs with $E$. cautella not infested with other insect pests or rot causes yet. The larvae pupate in silky cocoons under the external dry leaves of bulbs. 


\section{B- Population Studies}

Data presented in table (1) revealed that, three of the previous insect pests of onion bulbs, Carpophilus spp, E. amoenus and E. cautella were present in the store all over the year, while $A$. orientalis was only detected from May til September.

Population density of E. amoenus being considerably higher in 2008/9 than in 2009/10 season. The infestation in both seasons started in moderately level in May and increased reaching its highest density at August being 328 and 208 individuals/100 bulbs, respectively. The infestation then gradually decreased until March of the first season and February of the second one being 20 and 22 individuals/100 bulbs,respectively. In this respect, Ismail, et al, 1990, reported that, the larvae of $E$. amoenus reach its peak (153/10 bulbs) during the first week of July and another peak at mid August (120/10 bulbs). El-Sherif and Mahmoud (2008) reported that this insect frequently occurred throughout the whole storage period (from June to November) on onion. Also, Haydar and El-Sherif (1997) mentioned that, the activity of $E$. amoenus started by early February and reached its maximum during April, May and June.

Infestation with Carpophilus spp was moderate and its level was relatively higher in 2008/9 than 2009/10 season. The highest population was recorded in September being 84 and 69 individuals/100 bulbs, while the lowest density was in March or April being 3 and 4 individuals/100 bulbs per both seasons, respectively. In this respect, Abu-Hashish, (1998), found that the highest population of C. hemipterus was in August (212) and the lowest was in February (6) .

Also, a moderate infestation level with $E$. cautella was detected all over the year and the highest density was 22 and 30 individuals/100 bulbs in November, 2008/9 and October, 2009/10, respectively. The lowest population density was in June being 3 and 4 individual/100 bulbs during the $1^{\text {st }}$ and $2^{\text {nd }}$ year, respectively. In this respect, Venkatesh and David (2001) found that, the C. cautella infestation in storage increased with storage length, probably with decrease in relative contents of moisture, pyruvic acid and total sulfur.

The present study revealed that, the population density of $A$. orientalis had nearly a similar trend in both seasons and was found only from April until September. The maximum population density was recorded in July and June for the first and second season being 73 and 61 individuals/100 bulbs, respectivly. In this respect, Gupta et al, (1991) reported that, A. orientalis and Carpophilus obsoletus infest onion bulbs in store in India. Also Mahmoud (2008), found that, $A$. orientalis attack onion bulbs in Assiut only from July until October. 
Table 1. Monthly counts of onion insects/100 bulbs in store, during 2008/9 and 2009/10 seasons.

\begin{tabular}{|c|c|c|c|c|c|c|c|c|}
\hline \multirow{2}{*}{ Month } & \multicolumn{2}{|c|}{ E. amoenus } & \multicolumn{2}{c|}{ Carpophilus spp } & \multicolumn{2}{c|}{ A. orientalis } & \multicolumn{2}{c|}{ E. cautella } \\
\cline { 2 - 10 } & $2008 / 9$ & $2009 / 10$ & $2008 / 9$ & $2009 / 10$ & $2008 / 9$ & $2009 / 10$ & $2008 / 9$ & $2009 / 10$ \\
\hline May & 38 & 96 & 33 & 26 & 22 & 18 & 8 & 3 \\
\hline June & 74 & 206 & 52 & 40 & 39 & 61 & 3 & 4 \\
\hline July & 179 & 161 & 80 & 62 & 73 & 36 & 5 & 8 \\
\hline August & 328 & 208 & 64 & 44 & 26 & 24 & 7 & 13 \\
\hline September & 184 & 89 & 84 & 69 & 24 & 36 & 16 & 13 \\
\hline October & 236 & 86 & 56 & 48 & - & - & 18 & 30 \\
\hline November & 142 & 58 & 38 & 36 & - & - & 22 & 14 \\
\hline December & 80 & 56 & 19 & 12 & - & - & 18 & 13 \\
\hline January & 64 & 24 & 7 & 8 & - & - & 12 & 5 \\
\hline February & 40 & 22 & 4 & 7 & - & - & 13 & 3 \\
\hline March & 20 & 28 & 3 & 5 & - & - & 5 & 7 \\
\hline April & 32 & 62 & 5 & 4 & 26 & 20 & 11 & 5 \\
\hline Total & 1417 & 1096 & 445 & 361 & 210 & 195 & 138 & 118 \\
\hline Mean & 118.1 & 91.3 & 37.1 & 30.1 & 17.5 & 16.3 & 11.5 & 9.8 \\
\hline
\end{tabular}

\section{C- Loss assessment}

\section{1- Infestation percent}

As shown in Table (2), the observed species could be arranged in a descending order according to the total percentage of infestation as: $E$. amoenus (onion bulb fly), E. cautella (almond moth), Carpophilus spp. (dried fruit beetle), and Athrigona orientalis.

The maximum infestation percent for $E$. amoenus was in August ranged 20 $22 \%$, while the lowest was $3 \%$ in March of both seasons. In Assiut El-Sherif and Mahmoud (2008) found that, the infestation of onion bulbs with E. amoenus was generally low $(2.6 \%)$ in June, moderate $(7.3 \%)$ in July, relatively high $(12.2 \%)$ in August and $(10.9 \%)$ in September. The infestation decreased again $(7.3 \%)$ in October, and became low (4.0\%) in November.

As for the infestation with E. cautella, it reached the highest level, $17-20 \%$ in October and November. Its lowest record (3\%) was found in June for both seasons.

The highest infestation percent with Carpophilus spp. was recorded in October being 15 and $11 \%$ for both seasons, while the lowest percent was $2 \%$ in March. 
A. orientalis infestation started weakly and similarly continued between 2 $7 \%$ in both seasons from April to September.

In general, regardless the insect species, the percent of infestation onion was relatively higher $(2-10.8 \%)$ in the first season than that $(1.5-8.3 \%)$ in the second season. At the same time, the infestation results pointed to that Giza 20 onion variety seemed to be a more favorable food for the two species of $E$. amoenus and $E$. cautella than the other species, Table (2).

Table 2. Infestation percent with onion insects in store, during 2008/9 and 2009/10 seasons.

\begin{tabular}{|c|c|c|c|c|c|c|c|c|}
\hline \multirow{2}{*}{ SP. } & \multicolumn{2}{|c|}{ E. amoenus } & \multicolumn{2}{|c|}{ E. cautella } & \multicolumn{2}{c|}{ Carpophilus spp } & \multicolumn{2}{c|}{ A. orientalis } \\
\cline { 2 - 10 } Month & $2008 / 9$ & $2009 / 10$ & $2008 / 9$ & $2009 / 10$ & $2008 / 9$ & $2009 / 10$ & $2008 / 9$ & $2009 / 10$ \\
\hline May & 4 & 11 & 8 & 3 & 4 & 3 & 2 & 2 \\
\hline June & 12 & 10 & 3 & 3 & 11 & 8 & 4 & 5 \\
\hline July & 21 & 15 & 4 & 6 & 12 & 9 & 7 & 4 \\
\hline August & 22 & 20 & 6 & 10 & 9 & 10 & 6 & 2 \\
\hline September & 17 & 9 & 9 & 12 & 12 & 9 & 4 & 3 \\
\hline October & 17 & 9 & 11 & 17 & 15 & 11 & - & - \\
\hline November & 13 & 6 & 20 & 12 & 9 & 8 & - & - \\
\hline December & 5 & 5 & 16 & 11 & 4 & 5 & - & - \\
\hline January & 5 & 3 & 9 & 4 & 3 & 2 & - & - \\
\hline February & 6 & 3 & 10 & 3 & 2 & 3 & - & - \\
\hline March & 3 & 3 & 3 & 6 & 2 & 2 & - & - \\
\hline April & 5 & 6 & 7 & 5 & 3 & 2 & 1 & 2 \\
\hline Mean & 10.8 & 8.3 & 8.8 & 7.7 & 7.2 & 6.0 & 2.0 & 1.5 \\
\hline
\end{tabular}

\section{2- Weight loss}

As shown in Table (3) the data revealed that, the total loss of bulb weight was higher in 2008/2009 than 2009/2010 season being 32.36 and 29.67\%, respectively. The insect pests, of Carpophilus spp, E. amoenus and $A$. orientalis caused most yield loss and may combine in the same bulb than E. cautella. The previous insect pests caused 25.78 and $24.1 \%$ of the total weight loss. 
Table 3. Loss percent in stored onion weight due to infestation with insect pests during $2008 / 9$ and $2009 / 10$ seasons.

\begin{tabular}{|c|c|c|c|c|c|c|}
\hline & \multicolumn{3}{|c|}{ Mean weight of 100 bulbs (kg.) } & \multicolumn{3}{|c|}{ Weight reduction \% } \\
\hline & \multirow{2}{*}{$\begin{array}{c}\text { Before storage } \\
\text { Healthy }\end{array}$} & \multicolumn{2}{|c|}{ After storage } & \multirow{2}{*}{ Natural } & \multirow{2}{*}{ Total } & \multirow{2}{*}{$\begin{array}{l}\text { Insect } \\
\text { pests* }\end{array}$} \\
\hline & & Infested bulbs* & Healthy bulbs & & & \\
\hline $2008 / 9$ & 11.71 & 7.92 & 10.95 & 6.49 & 32.362 & 25.78 \\
\hline $2009 / 10$ & 12.20 & 8.58 & 11.52 & 5.57 & 29.67 & 24.10 \\
\hline Mean & 11.96 & 8.25 & 11.24 & 6.03 & 31.02 & 24.94 \\
\hline
\end{tabular}

$*$ Insect pests $=$ E. amoenus, Carpophilus spp, E. cautella and A. orientalis

\section{REFERENCES}

1. Abu-Hashish, T. A. 1998. Monthly population density and laboratory rearing of Carpophilus hemipterus (L.) (Coleoptera: Nitidulidae) on onion prepared for exportation and dehydration. Ann. Of Agric. Sc., Moshtohor, 36 (3) 1969-1980.

2. El-Sherif, S. I. and H. H. Mahmoud. 2008. The population densities of two major insect pests of onion, the onion thrips (Thrips tabaci Lind.) in fields and the onion bulb fly (Eumerus amoenus Loew.) in stores. Bull. of Fac. of Agric., Cairo Univ., 59 (4) $326-332$.

3. El-Sherif, S. I. and H. H. Mahmoud. 2008. Insect fauna of onion plants in seedbeds, fields and stores in Assiut Governorate. Bull. Fac. of Agric., Cairo Univ., 59 (4) $318-325$.

4. Gupta, R. P., K. J. Srivastava and U. B. Pandey. 1991. Management of onion diseases and insect pests in India. Onion Newsletter for the Tropics. 3, 15-17.

5. Haydar, M. F. and L.S. El-Sherif. 1987. Ecological aspects and developing method of onion pest control. Bull. Soc. Entomol. Egypt, econ. Ser., 16: 119-126.

6. Ismail, I. I., M. .M. El Bolok and H. A. El Shabrawy. 1990. Population fluctuation of two onion bulb flies (E. amoenus Loew and E. vestitus Bez., Syrphidae, Diptera) and their parasites in the store. Bull. Soc. Entomol. Egypt, 69, 89-96. 
7. Mahmoud, H. H. 2008. Ecological studies on certain insect pests of onion with special emphasis on the onion bulb fly Eumerus amoenus Loew. (Diptera : Syrphidae). Ph.D. Thesis, Fac. Agric., Cairo Univ., Egypt.

8. Massry, S. H. D. 2002. Ecological and bio-control studies on some pests infesting onion and garlic crops. M. Sc. Thesis, Fac. Agric., Menoufia Univ., Egypt.

9. Sherif, S. I. and H. H. Mahmoud. 2008. The population densities of two major insect pests of onion, the onion thrips (Thrips tabaci Lind.) in fields and the onion bulb fly (Eumerus amoenus Loew.) in stores. Bull. of Fac. of Agric., Cairo Univ., 59 (4) $326-332$.

10. Venkatesh, D. and P. M. M. David. 2001. Some observations on the fig moth, Cadra cautella (Wlk.) infesting onions in storage. Entomon. 26 (3/4) 323-326. 


\title{
دراسات عن أهم الآفات الحشرية التي تصيب البصل في المخزن وتأثيرها على الفقد
} في المحصول بمحافظة الفيوم

\author{
ابر اهيم مخيمر صبرة حسام احم صالح ابراهيم عبدالحميد الصباغ \\ معرد بحوث وقاية النباتات - مركز البحوث الزراعية - الدقى - الجيزة
}

أجريت تجربة لتحديد أهم الآفات التي تصيب محصول البصل في المخزن تحت ظروف

محافظة الفيوم وكذا دراسة أعر اض الإصابة وتعداد هذه الآفات وتحديد نسبة وكمية الضرر الناتج

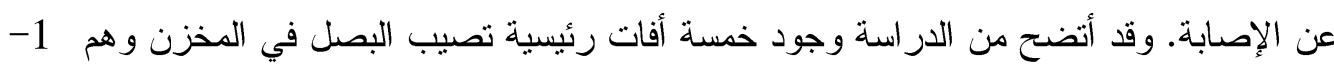
ذبابة البصل الكبيرة (Eumerus amoenus Loew) 2- فر الثة المو اد المخزونة (Ephestia cautella C. Carpophilus immaculatus Luc. و (Walker) الاصائ (hemipterus F. الأصابة لكلا من Carpophilus spp. E. Cautella . . و أظهرت دراسة التعداد أن الأربعة افات ونات

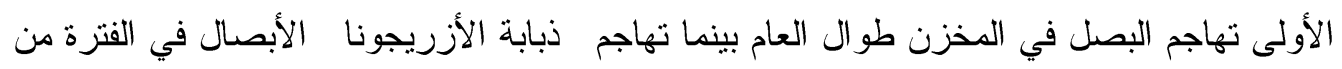

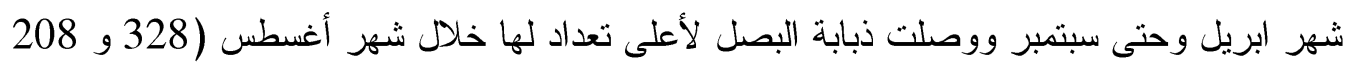

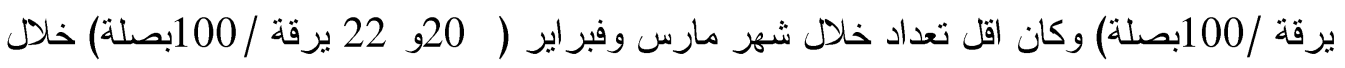
موسمي 2009/2008 و 2010/2009 على الترتيب وكان أعلى تعداد لخنفستي الفاكهة المجفقة

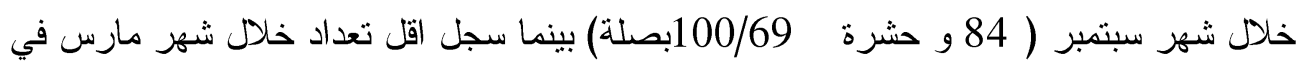

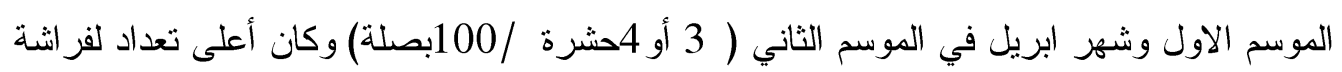
المو اد المخزونة خلال شهر نوفمبر في الموسم الأول وشهر اكتوبرفي الموسم الثاني ( 22 أو 30

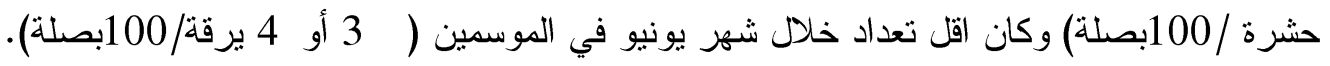
وكانت أعلى كثافة عددية لذبابة ألازريجونا خلال شهر يوليو في الموسم الأول وشهر يونية للموسم

$$
\text { الثاني (73 و } 61 \text { يرقة/100/ وبلة بصلة). }
$$

\section{وتم دراسة تأثير هذه الآثات على الفقد في المحصول بطريقتين:}

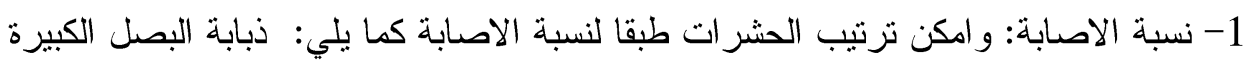

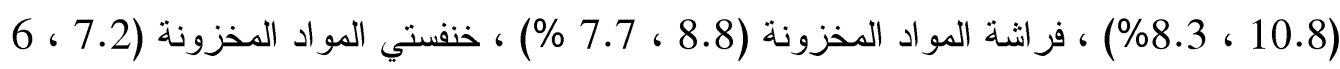

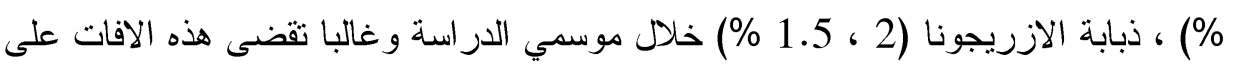

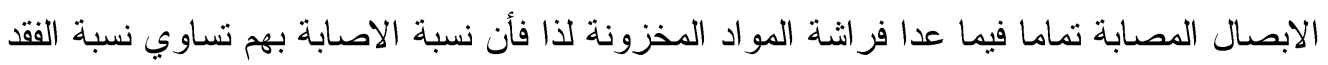
في المحصول. 2- الوزن المفقود: أتضح من الدراسة تداخل الاصابة في نفس البصلة بكلا من ذبابة البصل الكبيرة

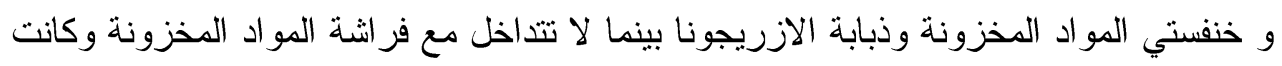

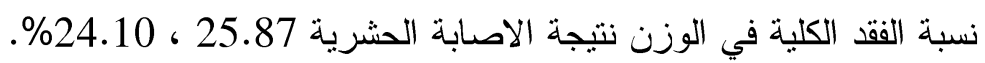

